\title{
Effect of Science Teachers' Knowledge, Attitudes and Skills on Out- Door Instruction, At Selected Secondary Schools in Uasin-Gishu County, Kenya
}

\author{
Stella Kabesa: University of Eldoret, Kenya.
}

\begin{abstract}
Outdoor learning usually refers to organized learning that takes place outside the confines of a classroom. This study aims to empirically examine the effects of teachers' knowledge, attitude and skills on out-door instruction in Kenya. The study adapted a survey research design. A sample of 135 teachers was randomly obtained from a population of 318 teachers. The response rate was 77.59 per cent. Data was collected using both closed and open ended questionnaires. Data was analyzed by employing descriptive statistics, Pearson correlation and multiple regression analysis. The findings revealed that teachers 'Knowledge, Attitude and Skills (KAS) are positively associated with out-of-classroom instruction in Kenya. The generalizability of the findings is limited as the study focused only in Kenya. Based on the findings, the study recommends that schools should focus on encouraging development of knowledge, attitude and skills in teachers thus promoting the use of out-door instruction in science. This study contributes to the theoretical and practical knowledge by providing the evidence about factors affecting science teaching. It is also expected to extend the knowledge on out-door learning.
\end{abstract}

Key words: Attitude, Knowledge, Science learning, Skills, Out-door instruction.

\section{Introduction}

Science can be taught through formal classroom teaching, practical work and out-of-classroom activities Michie (1999). Outdoor learning usually refers to organized learning that takes place outside the confines of a classroom. Education outside the classroom describes school curriculum learning, other than with a class of students sitting in a room with a teacher and books. It encompasses biology field trips and searching for insects in the school garden/ compound, orchard, pond, hedge, market places, community tree plantations, rubbish damps, plant and animal habitats; visiting museums, zoos, parks, botanical gardens, dams, lakes wildlife areas (Mutebi \& Matovu, 1993). It is a concept currently enjoying a revival because of the recognition of benefits from the more active. Beasley, Butler, and Satterthwait (2001) argues that scientists recognize that knowledge based upon experimental results and accurate observations is gained through a variety of experiences. Thus, the role of the field learning becomes a key component in understanding science. Out-of-classroom activities and inquiry as suggested by Orion (1993) provides students with opportunities to question, observe, sample, experience, and experiment with scientific phenomena in their quest for knowledge of living things. Out-door learning can bring about reinforcement between the affective and the cognitive domain, with each influencing the other and providing a bridge to higher order learning. Teachers' ${ }^{6}$ knowledge, attitude and skills are therefore key for effective implementation of out-door instruction. The basic philosophy underlying Secondary school science curriculum is "to provide students with the knowledge about their own body structure and environment, getting them to gain the ability to use

Vol. 1, No. 4, pp. 240-250

financial support. Ongeti for his tireless ass late Prof. the development and final completion or study. Special thanks go to the School of Education Moi University, lecturers and Department of Curriculum, Instruction Educational Media for allowing the equipment and facilities and to the Commission for Science, Technology this study.

Article History:

Revised: 26 September 2018

Accepted: 1 November 2018

Published: 28 December 2018

C 2018 by the authors: licensee Academic

Publishing Group 


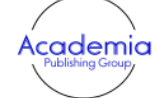

International Journal of Educational Studies Vol. 1, No. 4, pp. 240-250

2018

DOI: 10.53935/2641-533x.v1i4.93

Funding: This study received no specific

financial support.

Acknowledgement: Author wish to expres sincere gratitude to the late Prof. Khaemba Ongeti for his tireless assistance and direction in the development and final completion of this study. Special thanks go to the School of Education Moi University, lecturers and the Department of Curriculum, Instruction and Educational Media for allowing the use of the equipment and facilities and to the National Commission for Science, Technology and Innovation (NACOSTI) for approval to conduct this study.

Article History:

Received: 25 July 2018

Revised: 26 September 2018

Revised: 26 September 2018

Accepted: 1 November 2018

he authors: licensee Academic

Publishing Group scientific knowledge in daily life, share this knowledge with others, develop a positive attitude towards biology, gain an understanding of a wholesome life and to have scientific curiosity about biology" (Ministry of Education, 2008). The intended role for the teacher is stated in the guide to be that of a facilitator or a guide who enables students to comprehend the subject matter optimally using all their senses, and not just listening, learning by interpreting, integrating, and questioning. The teacher is also expected to try and get the students to be active learners by encouraging them to do research and experiments. Teachers should provide the students with interesting concepts and issues and give interesting assignments and projects on the subject matter. Practical work in science provide are indispensable learning experiences thus, various studies have been carried out on science teachers' knowledge, attitudes towards out-door learning (Falk, Martin, \& Balling, 1999; Fido \& Gayford, 2002; Muse, Chiarelott, \& Davidman, 2002).

Despite the significance of out-door learning, there are few studies done to empirically test the relationship between teachers' knowledge, attitude and skills on out-door learning. It is therefore assumed that this study will fill this gap in science education in Kenya by empirically testing these variables in the same context. This study hence seeks to determine the effect of science teachers' knowledge, attitudes and skills on the use of out-door instruction in secondary schools in Kenya.

\section{Literature Review}

\subsection{Out-Door Learning}

Out-door learning are planned learning activities that are designed to take place outside the classroom. They provide learners with opportunities for direct hands-on experiences that can be useful for transition from a concrete to abstract level of cognition as described by Piaget (1990). All learning is a mixture of firsthand experience and received information and ideas, only a limited part of which can be acquired in the classroom Price and Hein (1999). Learning out-side the classroom has potential to encourage meaningful learning by moving between the abstract and concrete as well as transforming experience into knowledge through reflection and communication. Out-door learning may provide the only opportunity for students to investigate living animals and plants which are interacting with each other and the world around them (Hillcox, 2003). The report from a Field Studies Council recommended that out-door learning should be a compulsory part of the science curriculum (Barker, Slingsby, \& Tilling, 2002). (Nundy, 1999a) pointed out that out-door learning activities are capable not only of generating positive cognitive and affective learning amongst students, but this may be enhanced significantly compared to that achievable within a classroom environment. Out-door learning provide an opportunity for teachers to develop a different and, potentially, more positive and productive relationship with their students. It often involves students working together with peers; the dynamics and interrelationships developed whilst working in groups can have a huge influence on how students develop socially (Dillon et al., 2005). According to Jones (2000), out-door learning provide one of the few places in a science curriculum where students quite literally observe the real world.

The outdoor classroom provides a link between theoretical aspects of biology and issues which affect our homes, communities and the world around us. Out-door activities can help to develop understanding, attitudes and values, and lead to a more enlightened commitment and action in areas such as citizenship, conservation, animal welfare, genetic engineering, biodiversity and sustainable development (Kelsey \& Steel, 2001)

\subsection{Knowledge}

The definition of knowledge as a term can be traced back to the time of Socrates. Plato suggested that knowledge has three components: beliefs, truth, and justification (Woolfolk \& Murphy, 1999). In the traditional philosophical literature, knowledge depends on a - truth condition\| that is being agreed upon in a community of people (Richardson, 1996). Based upon this definition, knowledge is a belief that meets two conditions: (a) the truth of what is believed and (b) the justification someone has for believing it Woolfolk and Murphy (1999). Alexander, Schallert, and Hare stated that beliefs are a category of knowledge and define knowledge as -encompasses all that a person knows or believes to be true, whether or not it is verified as true in some sort of objective or external wayll (Woolfolk \& Murphy, 1999). The null hypothesis hence states that, HO$_{1}$ : There is no significant relationship between teachers' knowledge and their use of out-door instruction. 


\subsection{Attitude}

Abelson (1979) defined attitudes in terms of people manipulating knowledge for a particular purpose or under a necessary circumstance. According to Brown and Cooney (1982), attitudes are dispositions to action and major determinants of behavior. Rokeach (1972) defined attitudes as -any simple proposition, conscious or unconscious, inferred from what a person says or does, capable of being preceded by the phrase I believe that ${ }^{\natural} \|$ (p. 113). Rokeach discussed three kinds of attitudes: descriptive or existential attitudes, evaluative attitudes and prescriptive or exhortatory attitudes. Rokeach (1972) suggested that all attitudes have three components: a cognitive component, an affective component and a behavioral component. A cognitive component represents a person's knowledge about what is true or false, desirable or undesirable. An affective component of the attitudes is capable of arousing affect of varying intensity centering on the object of the attitudes, taking a positive or negative position in an argument. A behavioral component of the attitudes leads to action when it is activated. According to Rokeach, the nature of attitudes is somewhat similar to the structure of an atom in terms of the ways in which attitudes are organized. Rokeach claims that some of the attitudes (core attitudes) are more central, more connected to others (peripheral), and more resistant to change. Moreover, Ackermann (1972) examined attitudes in four different categories as behavioral attitudes, unconscious attitudes, conscious attitudes, and rational attitudes. Behavioral attitudes are not distinguished simply because of fixed behavioral patterns that anyone holding a certain attitudes will exhibit. Rather unconscious attitudes long-standing attitudes that can influence behavior over a long period of time but resist recognition by the agent. Unlike behavioral attitudes, unconscious attitudes cannot be interpreted from behaviors. Behavioral attitudes, by contrast, will be thought of as non-conscious rather than unconscious. Behavioral attitudes are important in human action where the agent encounters no difficulty, so that his attitudes do not require scrutiny at the consciousness level. Conscious attitudes are any attitudes a person has explicitly formulated and is aware of. Rational attitudes are defined as a philosophical idealization of actual attitudes structures. Based upon a literature review of attitudes, Pajares (1992) defined attitudes as an individual's judgment of the truth or falsity of a proposition, a judgment that can only be inferred from a collective understanding of what human beings say, intend, and doll (p. 316). Anthropologists, social psychologists, and philosophers have agreed upon a commonly accepted definition of attitudes; -attitudes are thought of as psychologically held understandings, premises, or propositions about the world that are felt to be truell (Richardson, 1996). In educational settings, Haney, Lumpe, and Czerniak (2003) defined attitudes as -one's convictions, philosophy, tenets, or opinions about teaching and learningl (p. 367). Hence the null hypothesis,

$\mathbf{H O}_{2}$ : There is no significant relaStionship between teachers' attitudes and their use of out-door instruction.

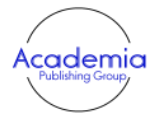

International Journal of Educational Studies Vol. 1, No. 4, pp. 240-250

2018

DOI: 10.53935/2641-533x.v1i4.93

Funding: This study received no specific

financial support.

Acknowledgement: Author wish to expres sincere gratitude to the late Prof. Khaemba Ongeti for his tireless assistance and direction in the development and final completion of this study. Special thanks go to the School of Education Moi University, lecturers and the Department of Curriculum, Instruction and Educational Media for allowing the use of the equipment and facilities and to the National Commission for Science, Technology and Innovation (NACOSTI) for approval to conduct this study.

Article History:

Received: 25 July 2018

Revised: 26 September 2018

Pubtished 28 December 2018

Published. 28 Decente

the authors; licensee Academic

Publishing Group
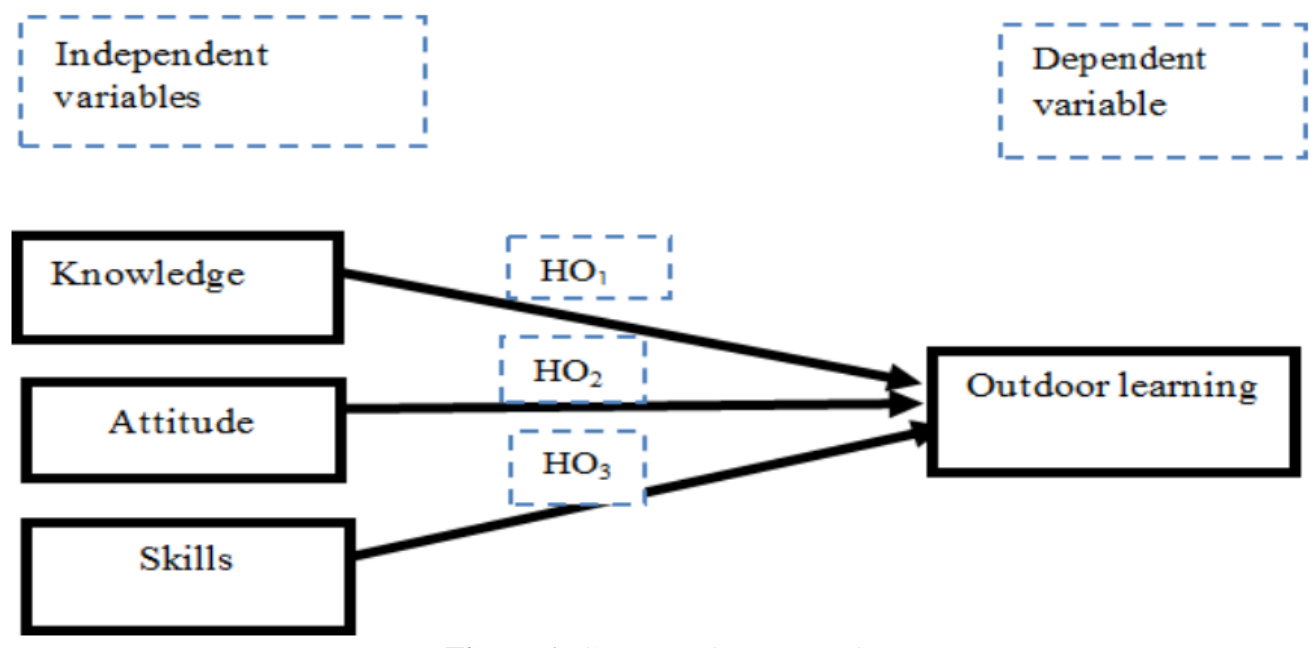

Figure-1. Conceptual Framework.

\subsection{Skills}

Skill refers to the ability of teachers to plan, organize and execute out-door learning activities and achieve the desired learning outcomes. It follows from this, that out-door learning activities need to be given careful 
consideration at the stage of overall curriculum design, and that the pattern of field teaching across the school program should be carefully thought through. Out-door learning activities should be conceived both within their wider academic context and as a distinctive part of the curriculum which requires design in its own right. Teachers need to ensure that students may well benefit from experiencing not only different types of out-door activities but also different levels of challenge. Skill usually requires certain environmental stimuli and situations to assess the level of skill being shown and used, thus the null hypotheses,

$\mathbf{H O}_{3}$ : There is no significant relation between teachers' skills and their use of out-door instruction.

\section{Materials and Methods}

\subsection{Research Design, Sample Size and Sampling Technique}

This study used a survey research design. The target population included 318 science teachers from 159 secondary schools in Uasin Gishu County, Kenya. A sample size of 135 respondents was randomly selected for the study. The questionnaires were used to collect data.

\subsection{Measurement of Variables}

Out-door activities were measured using 7 items which were rated on a 5-point likert scale ranging from 1 (never), 2 (rarely), 3 (sometimes), 4 (often) and 5 (always). 14 items measuring teachers' knowledge on significance of field activities in biology, were also rated on a 5-point likert scale ranging from 1 (strongly disagree), 2 (disagree), 3 (undecided), 4 (agree) and 5 (strongly agree). The next 27 items measured teachers ${ }^{6}$ attitude and skills on use of field activities both on a 5-point likert scale ranging from 1 (strongly disagree) to 5 (strongly agree). Indexes were obtained by computing the average scores. The results of the reliability coefficient $(\alpha)$ of each of the independent variables were as follows, Knowledge (.701); Attitude (.802); Skills (.799). Data was analyzed using SPSS version 21.Descriptive statistics of the respondents was obtained. Pearson correlation was used to establish associations while multiple regression was used to establish the cause effect among the variables.

\section{Results}

\subsection{Background Characteristics of Participant Classroom Teachers}

According to the results, among participant teachers $(\mathrm{N}=135), 27 \%(\mathrm{n}=37)$ of them were females whereas $73 \%(n=98)$ of them were male. The age of teachers ranged from below 30 years to above 46 years. Approximately $52 \%(\mathrm{n}=70)$ of them were aged below 30 whereas the age of approximately $16 \%(\mathrm{n}=22)$ of them ranged from 31 to 35 . Also, $27 \%$ of them $(n=36)$ were aged between 36-40years, while 5\% $(n=7)$ were over 46 years. Considering their teaching experience, the table displays that the majority had less than ten years of experience $36 \%,(n=49)$ followed by teachers with experience of 10 to 20 years $27 \%$, $(n=36)$. The obtained data also revealed that $14 \%$ of participant classroom teachers had over 20 years of teaching experience.

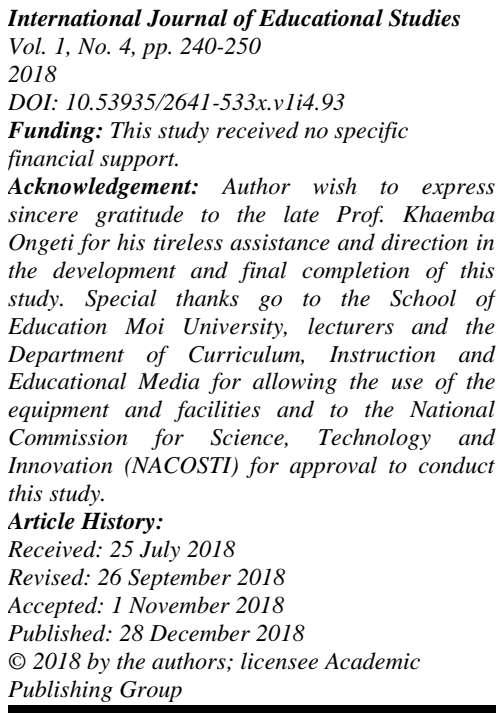

\subsection{Descriptive Results \\ 4.2.1. Teachers' Knowledge of Field Activities}

The teachers' scores on knowledge of field activities in biology was moderate $(\mathrm{M}=4.23, \mathrm{SD}=.455)$. About $100 \%$ the participants indicated that field activities develops students' skills in observation, measurement, and in data and specimen collection $(\mathrm{M}=4.72, \mathrm{SD}=.451)$, stating that they provide experiential learning $(\mathrm{M}=4.43$, $\mathrm{SD}=.451)$, and promotes learning through case studies examined at first hand $(\mathrm{M}=4.30, \mathrm{SD}=.458)$. A little more than $93 \%$, stated that field activities promotes students' transferable skills $(\mathrm{M}=4.47, \mathrm{SD}=.621)$, while almost $90 \%$ thought that field activities develops good working relations amongst students and between staff and students $(M=4.13, S D=.918)$. Nearly all participant teachers agreed that field activities ensures that students learn how to work safely in the field $(\mathrm{M}=4.35, \mathrm{SD}=.478)$ and help link theory with practice by relating knowledge derived from reading, lectures and laboratory work to information and evidence gained in the field $(\mathrm{M}=4.70, \mathrm{SD}=.458)$. 
Table-1. Demographic Background of Participant Classroom Teachers (N=135).

\begin{tabular}{llll}
\hline \multicolumn{2}{c}{ Table-1. Demographic Background of Participant Classroom Teachers (N=135). } \\
\hline Gender & & Frequency & Percentage \\
& Male & 98 & 72.6 \\
Age & Female & 37 & 27.4 \\
& & & \\
& 30years and below & 70 & 51.9 \\
& 31-35 years & 22 & 16.32 \\
Highest Professional qualification & 36- 40 years & 7 & 5.2 \\
& Over 40 years & 36 & 26.7 \\
& BEd(Sc) & 82 & 60.7 \\
& BSC with Dip Ed & 47 & 34.8 \\
& Med & 6 & 4.4 \\
Teaching Experience & MSC with Ed & 0 & 0 \\
& & & 36.3 \\
& Less than 5 years & 49 & 10.4 \\
& 6- 10 year & 14 & 26.7
\end{tabular}

Table-2. Teachers' Knowledge of Field Activities in Biology.

\begin{tabular}{lll}
\hline Knowledge & Mean & $\begin{array}{l}\text { Std. } \\
\text { Deviation }\end{array}$ \\
\hline $\begin{array}{l}\text { Field activities develop students' skills in observation, measurement, and } \\
\text { in data }\end{array}$ & 4.72 & 0.451 \\
and specimen collection & & \\
Field activities provide experiential learning & 4.43 & 0.451 \\
Field activities promote learning through case studies examined at first & 4.30 & 0.458 \\
hand & & \\
Field activities promote students' transferable skills & 4.47 & 0.621 \\
Field activities develop good working relations amongst students and & 4.13 & 0.918 \\
between & & \\
staff and students & & \\
Field activities ensure that students learn how to work safely in the field. & 4.35 & 0.478 \\
Field activities link theory with practice by relating knowledge derived & 4.70 & 0.458 \\
from reading, lectures and laboratory work to information and evidence & & \\
gained in the & & \\
field & & \\
Field activities help to deliver curriculum content & 4.47 & 0.544 \\
Field activities develop fieldwork skills & 4.44 & 0.606 \\
Field activities help to complete coursework & 3.73 & 1.154 \\
Field activities provide evidence for key skills & 4.46 & 0.620 \\
Field activities promote personal development & 4.32 & 0.568 \\
Field activities build progression to the next level & 4.07 & 0.951 \\
Field activities promote subject recruitment & 4.01 & 1.065 \\
Mean & 3.761 & .321 \\
\hline
\end{tabular}

International Journal of Educational Studies
Vol. 1, No. 4, pp. 240-250
2018
DOI: 10.53935/2641-533x.v1i4.93
Funding: This study received no specific
financial support.
Acknowledgement: Author wish to express
sincere gratitude to the late Prof. Khaemba
Ongeti for his tireless assistance and direction in
the development and final completion of this
study. Special thanks go to the School of
Education Moi University, lecturers and the
Department of Curriculum, Instruction and
Educational Media for allowing the use of the
equipment and facilities and to the National
Commission for Science, Technology and
Innovation (NACOSTI) for approval to conduct
this study.
Article History:
Received: 25 July 2018
Revised: 26 September 2018
Accepted: 1 November 2018
Published: 28 December 2018
() 2018 by the authors; licensee Academic
Publishing Group $\mid 244$
Also, close to $98 \%$ of the teachers agreed that field activities helps to deliver curriculum content $(\mathrm{M}=4.47$, $\mathrm{SD}=.544)$ and enables students develop fieldwork skills $(\mathrm{M}=4.44, \mathrm{SD}=.606)$. A little more than $93 \%$ agreed that field activities work helps to complete coursework $(\mathrm{M}=3.73, \mathrm{SD}=1.154)$, with almost all teachers accepting that field activities provides evidence for key learning skills $(\mathrm{M}=4.46, \mathrm{SD}=.620)$, promoting personal development( $\mathrm{M}=4.32, \mathrm{SD}=.568)$. Majority of classroom, almost $84 \%$ stated that field activities builds 
progression to the next learning level $(\mathrm{M}=4.07, \mathrm{SD}=.951)$, and finally that field activities promotes subject recruitment $(\mathrm{M}=4.01, \mathrm{SD}=1.065)$.

\subsubsection{Teacher's Attitude Towards Field Activities}

About $100 \%$ of the participants indicated that they were knowledgeable about the significance of fieldwork in biology $(\mathrm{M}=4.36, \mathrm{SD}=.480)$ and that, they $72 \%$, have adequate content knowledge to effectively teach the lessons and activities $(\mathrm{M}=4.30, \mathrm{SD}=.820)$. A good number of classroom teachers more than $88 \%$ agreed that they have the confidence of conducting field activities $(\mathrm{M}=4.37, \mathrm{SD}=.688)$. Close to $95 \%$ of the respondents indicated that the use of field activities does not complicate a teacher's job $(\mathrm{M}=4.47, \mathrm{SD}=.596)$, and that $97 \%$ like to use field activities in biology teaching $(\mathrm{M}=4.37, \mathrm{SD}=.530)$. Approximately $88 \%$ said it is interesting to integrate field activities in teaching $(\mathrm{M}=4.34, \mathrm{SD}=.682)$ and nearly $100 \%$ of classroom teachers agreed that using field activities in teaching will increase students' motivation to learn biology ( $\mathrm{M}=4.71$, $\mathrm{SD}=.455)$. More than $90 \%$ of them agreed that using field activities in teaching improves effectiveness of teaching $(\mathrm{M}=4.61, \mathrm{SD}=.488)$, while nearly all respondents, $100 \%$ agreed that using field activities in teaching will make learning more effective $(\mathrm{M}=4.65, \mathrm{SD}=.478)$.

Table-3. Teacher's Attitude towards Field Activities.

\begin{tabular}{lll}
\hline Attitudes & Mean & Std. Deviation \\
\hline I am knowledgeable about the significance of fieldwork in biology & 4.36 & 0.480 \\
I have adequate content knowledge to effectively teach the lessons & and 4.30 & 0.820 \\
activities & 4.37 & 0.688 \\
I have the confidence of conducting field activities & 4.47 & 0.596 \\
Using field activities does not complicate a teacher's job & 4.37 & 0.530 \\
I like to use field activities in biology teaching & 4.34 & 0.682 \\
It is interesting to integrate field activities in teaching & 4.71 & 0.455 \\
Using field activities in teaching will increase students' motivation & 4.61 & 0.488 \\
Using field activities in teaching improves teaching effectiveness & 4.65 & 0.478 \\
Using field activities in teaching will make learning more effective & 4.37 & 0.780 \\
Using field activities in teaching will increase students' knowledge & 4.31 & 0.973 \\
Using field activities in teaching increases students' interest in subject matter & 4.27 & 0.910 \\
Using field activities in teaching enables students to get information faster & 4.20 & 1.158 \\
Using field activities in teaching encourages students' creativity & 3.60 & 1.477 \\
Using field activities in teaching helps increase students' self-confidence & 2.30 & 1.204 \\
Field work is a risky teaching approach & & 1.477 \\
The quality of teaching is likely to be compromised if field activities & 2.47 & \\
involved & 2.73 & 1.448 \\
Field activities disrupts normal learning & 3.53 & 1.292 \\
Delivery of fieldwork is "inspiring' to the students & 2.29 & 1.227 \\
Field activities are "tedious and dull' & 2.47 & 1.251 \\
Fear of accidents is an important influence on field work provision & 3.50 & 1.233 \\
Field activity sessions need to be accompanied by medical personnel & 4.01 & 1.072 \\
Teachers involved in field activities should be rewarded/ encouraged & 3.70 & .388 \\
Means & &
\end{tabular}

International Journal of Educational Studies Vol. 1, No. 4, pp. 240-250 2018

DOI: $10.53935 / 2641-533 x . v 1$ i4. 93 Funding: This study received no specific financial support.

Acknowledgement: Author wish to express sincere gratitude to the late Prof. Khaemba Ongeti for his tireless assistance and direction in the development and final completion of this study. Special thanks go to the School of Education Moi University, lecturers and the Department of Curriculum, Instruction and Educational Media for allowing the use of the equipment and facilities and to the National Commission for Science, Technology and Innovation (NACOSTI) for approval to conduct this study.

Article History:

Received: 25 July 2018

Revised: 26 September 2018

Published: 28 Decher 2018

Published: 28 December 2018

() 2018 by the authors; licensee Academic

| 245

Source: Survey Data.

A little more than $90 \%$ of the respondents agreed that using field activities in teaching will increase students ' knowledge( $\mathrm{M}=4.37, \mathrm{SD}=.780)$, and close to $93 \%$ said using field activities in teaching increases students' interest in subject matter $(\mathrm{M}=4.31, \mathrm{SD}=.973)$. Over $91 \%$ agreed to the statement that using field activities in teaching enables students to get information faster $(\mathrm{M}=4.27, \mathrm{SD}=.910)$, with $82 \%$ confirming that use of field activities in teaching encourages students' creativity $(\mathrm{M}=4.20, \mathrm{SD}=1.158)$. More than half of the respondents, 59\% agreed that using field activities in teaching helps increase students' self-confidence $(\mathrm{M}=3.60, \mathrm{SD}=1.477)$, whereas at least $64 \%$ accepting that the delivery of fieldwork is "inspiring' to the students $(M=3.53, S D=1.292)$. More than $63 \%$ of the teachers felt that field activity sessions need to be accompanied by medical personnel $(\mathrm{M}=3.50, \mathrm{SD}=1.233)$. Majority of teachers, $78 \%$, were of the view that 
teachers involved in field activities should be rewarded/ encouraged ( $\mathrm{M}=4.01, \mathrm{SD}=1.072)$.However, negatively worded statements received the least percentages, means and standard deviations, this include statements like; -Field work is a risky teaching approachl( $\mathrm{M}=2.30, \mathrm{SD}=1.204,16 \%)$,-The quality of teaching is likely to be compromised if field activities are involvedl(M=2.47,SD=1.477,25\%),-Field activities disrupts normal learning $(\mathrm{M}=2.73, \mathrm{SD}=1.448,37 \%), \quad$-Field activities are "tedious and dull' $(\mathrm{M}=2.29, \mathrm{SD}=1.227,26 \%)$, and - Fear of accidents is an important influence on field work provision $\|(\mathrm{M}=2.47, \mathrm{SD}=1.251,16 \%)$.

\subsubsection{Teacher's Skills on Field Activities}

According to Table 4 below, more than $95 \%$ of the participant classroom teachers agreed that they can plan and appropriately deliver fieldwork to achieve instructional objectives( $\mathrm{M}=4.19, \mathrm{SD}=0.496)$, with close to $65 \%$ confirming that they have received professional development training specifically for field activities(M=3.50, $\mathrm{SD}=1.158)$. A majority of the respondents $96 \%$ agreed that they frequently modify field activities for science lessons to meet the needs of diverse learners $(\mathrm{M}=4.27, \mathrm{SD}=0.539)$. It is also important to note that almost $90 \%$ of the respondents agreed that there is a very strong association with techniques, skills and coursework-and associated assessment-in secondary science( $\mathrm{M}=4.17, \mathrm{SD}=0.728)$. However, at least $77 \%$ of respondent teachers agreed that many trainee teachers are entering the profession with little previous fieldwork experience $(\mathrm{M}=3.81, \mathrm{SD}=0.918)$.

Table-4. Teacher's Skills on Field Activities

\begin{tabular}{lll}
\hline Skills & Mean & Std. Deviation \\
\hline $\begin{array}{l}\text { I can plan and appropriately deliver field activities to achieve instructional } \\
\text { objectives }\end{array}$ & 4.19 & 0.496 \\
$\begin{array}{l}\text { I have received professional development training specifically for field } \\
\text { activities }\end{array}$ & 3.50 & 1.158 \\
$\begin{array}{l}\text { I frequently modify field activities for science lessons to meet the needs of } \\
\text { diverse learners }\end{array}$ & 4.27 & 0.539 \\
$\begin{array}{l}\text { There is a very strong association with techniques, skills and coursework —and } \\
\text { associated assessment in secondary science }\end{array}$ & 4.17 & 0.728 \\
$\begin{array}{l}\text { Many trainee teachers are entering the profession with little previous field } \\
\text { activities' experience }\end{array}$ & 3.81 & 0.918 \\
Means & 3.840 & .369 \\
\hline Soirc:Sur
\end{tabular}

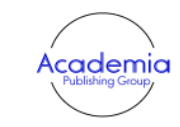

International Journal of Educational Studies Vol. 1, No. 4, pp. 240-250 2018

DOI: $10.53935 / 2641-533 x$.vli4.93

Funding: This study received no specific

financial support.

Acknowledgement: Author wish to express Acknowledgement: Author wish to express
sincere gratitude to the late Prof. Khaembo sincere gratitude to the late Prof. Khaemba
Ongeti for his tireless assistance and direction in Ongeti for his tireless assistance and direction in the development and final completion of this study. Special thanks go to the School of Education Moi University, lecturers and the Department of Curriculum, Instruction and Educational Media for allowing the use of the equipment and facilities and to the National Commission for Science, Technology and Innovation (NACOSTI) for approval to conduct this study.

Article History:

Received: 25 July 2018

Revised: 26 September 2018

Revised. 26 September 2018

Accepled: 28 Decenber 2018

(1) 2018 by the authors; license

2018 by the authors; licensee Academic

| 246

\subsection{Correlation Analyses}

The association between the independent variables and dependent variable were found to be statistically significant at level $p<0.01$, In other words, knowledge $(\mathrm{r}=0.639, \mathrm{p}<0.01)$, attitude $(\mathrm{r}=0.735, \mathrm{p}<0.01)$, skills $(r=0.586, p<0.01)$ correlated to the use of outdoor instruction.

\begin{tabular}{lllll}
\multicolumn{5}{c}{ Table-5. Correlations. } \\
\hline Measures & Field Activities & Knowledge & Attitude & Skills \\
\hline Field Activities & 1 & $.639^{* *}$ & $.735^{* *}$ & $.586^{* *}$ \\
Knowledge & $.639^{* *}$ & 1 & $.591^{* *}$ & $.434^{* *}$ \\
Attitude & $.735^{* *}$ & $.591^{* *}$ & 1 & $.509^{* *}$ \\
Skills & $.586^{* *}$ & $.434^{* *}$ & $.509^{* *}$ & 1 \\
\hline Note: **. Correlation is significant at the 0.01 level (2-tailed).N=135. &
\end{tabular}

\subsection{Hypotheses Testing}

Analysis of Variance was computed to establish the relationship between the dependent variable and the independent variables. The F-statistics produced $(\mathrm{F}=50.769)$ was significant at 1 per cent level $(\mathrm{Sig}$. $\mathrm{F}<$ 0.001 ), thus confirming the fitness of the model. The coefficient of determination $\mathrm{R}^{2}$ value was 70.4 per cent. This indicated that 70.4 per cent of the variation in dependent variable (use of out-door activities) was explained and predicted by independent variables. The beta coefficient for teachers knowledge was .246, 
$\mathrm{t}=3.959, \mathrm{p}<0.000$. Due to the low $\mathrm{p}$ - value associated with t-ratio, the null hypothesis $\left(\mathrm{H} o_{1}\right)$ is rejected. Therefore there is a statistically significant relationship between teachers' ${ }^{6}$ knowledge and their use of outdoor activities in science instruction. The second hypothesis was not supported. It aimed at finding out if there is a significant relationship between teachers' attitude and their use of out-door activities in science instruction. The beta coefficient for teachers' attitude is $.326, t=4.749, p<0.000$. Since the $p$-value associated with t-ratio is low, the null hypothesis $\left(\mathrm{Ho}_{2}\right)$ is rejected. Therefore there is a statistically significant relationship between teachers ${ }^{6}$ attitude and their use of out-door activities in science instruction. The third hypothesis addressed the question, -Is there a significant relationship between teachers' skills and their use of out-door activities in science instruction. The null hypothesis is that: There is no significant relationship between teachers' skills and their use of out-door activities in science instruction. The beta coefficient for teachers skills is $.143, \mathrm{t}=2.370, \mathrm{p}<0.05$. Due to the low $\mathrm{p}$-value associated with $\mathrm{t}$-ratio, the null hypothesis $\left(\mathrm{Ho}_{3}\right)$ is rejected. Therefore there is a statistically significant relationship between teachers' skills and their use of out-door activities in science instruction.

\begin{tabular}{llllll}
\multicolumn{7}{c}{ Table-6. Regression Analysis Results. } \\
\hline Predictor Variables & $\boldsymbol{\beta}$ & $\boldsymbol{t}$ - value & Sig. & Tolerance & VIF \\
\hline Knowledge & .246 & 3.959 & .000 & .598 & 1.673 \\
Attitude & .326 & 4.749 & .000 & .490 & 2.040 \\
Skills & .143 & 2.370 & .019 & .633 & 1.581 \\
$\mathrm{R}^{2}$ & $.704 * *$ & & & & \\
Adjusted $\mathrm{R}^{2}$ & .69 & & & & \\
F statistics & $50.769 * *$ & & & \\
\hline Note: Dependent variable outdoor instruction: **P<001.
\end{tabular}

\section{Discussion of Findings}

The findings of this study indicated that the majority of classroom teachers agreed with statements measuring their knowledge on the significance of out-door activities and their role in instruction. Inadequate teacher knowledge in science (Frank \& Enocks, 1982), Hurd (1982) has been admitted by teachers as key to effectively teaching science. There is a general agreement that lack of background in science knowledge significantly contributes to hesitancy and possible inability to deliver effective science instruction in classroom settings. Therefore, how much teachers know about science content is important for teacher education program. In this sense, results of this study showed that teachers are aware of the role of out-of class activities in learning. This enables teachers facilitate the development of competent learning skills through the provision of supervised quality fieldwork experiences. It also enhances the development of learning activities and assignments that encompass the breadth and depth of knowledge in the profession and reinforce knowledge and skills leading to quality learning. Similarly, Tekaya, Martin, and Barman (2004) on their research in field activities reported that majority of the teachers' demonstrated knowledge of effective learning processes that identify individual learning styles and use appropriate and individualized techniques for students at their fieldwork education site. They also demonstrated accurate and current knowledge of outdoor activities and competencies to develop and maintain proficiency in out-door learning.

Analysis on teachers' attitude revealed that there was no significant difference between male and female teachers. This finding showed that there is no need for differentiated professional training in science instruction to improve science attitude toward biology teaching for the different sexes which is consistent with Tukmen and Bonnstetters (1999). Pearson Product-Moment Correlations were computed in exploring the possible relationship between attitude and the use of out-door activities in science teaching. The data from this study recorded significant correlations between attitude and the use of out-door activities in science teaching. In the literature, there are number of studies that consider the relationship between teachers' attitude and science teaching. For example, Manning (1982) and Lucas and Pooley (1982) found a significant relationship between the prospective teachers' attitudes and teaching science. Conversely, Stepans and McCornack (1985) found a negative relationship. Furthermore,Wenner (1993), Fastritzer and Boyer (1983) found no significant correlations between attitude and use of resources in teaching science. The result of present study indicated that in-service training does have an impact on teacher's attitude. Also, to explore the possible relationship between attitude and use of out-door activities in science teaching; Pearson Product-Moment Correlations

Vol. 1, No. 4, pp. 240-250

financial support. Ongeti for his tireless assite Prof. the development and fint complion study. Special thaks go to the Schor Department of Curriculum, Instruction and Equational Media for allowing the usc equipment and facilities and to the Commission for Science, Technology this study.

Article History:

Received: 25 July 2018

Revised: 26 September 2018

1 November 2018

Published: 28 December 2018

C 2018 by the authors: licensee Academic

Publishing Group 


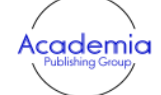

International Journal of Educational Studies Vol. 1, No. 4, pp. 240-250

2018

DOI: 10.53935/2641-533x.v1i4.93

Funding: This study received no specific

financial support.

Acknowledgement: Author wish to express sincere gratitude to the late Prof. Khaemba Ongeti for his tireless assistance and direction in the development and final completion of this study. Special thanks go to the School of Education Moi University, lecturers and the Department of Curriculum, Instruction and Educational Media for allowing the use of the equipment and facilities and to the National Commission for Science, Technology and Innovation (NACOSTI) for approval to conduct this study.

Article History:

Received: 25 July 2018

Revised: 26 September 2018

Revised: 26 September 2018

Published: 28 Decer 2018

(1) 2018 by the autho

by the authors; licensee Academi

Publishing Group were computed. Analyses revealed a significant correlation between attitudes and out-door activities in science instruction. The results showed that skills on out-of-class activities in science instruction significantly accounted for the use out-of-classroom activities in science teaching. And also, knowledge level and attitude toward science instruction each made a statistically significant contribution to the variation in the use of outof-classroom activities. This means, teachers with higher science knowledge level and positive attitude toward science teaching use out-of-class activities more often. Similarly, Haurey (1994) concluded that lower skill levels lead to decreased use of practical activities in science. Victor (1991) arrived at a conclusion similar to Haury's. On the other hand, Wenner (1993) found negative relationship between skills and teaching science in the 1992 study and the follow-up study in 1994 found a non-significant correlation. And also Ginns, Waters, and James (1990) observed no significant correlations between teachers' ${ }^{6}$ skills and science teaching efficiency.

\section{Conclusion}

Because of strong relationship between science teaching knowledge and science teaching behaviors, one goal of a teacher education program should be to increase teachers' knowledge, especially on out-of-class activities since teaching characteristics developed during training programs will cause a permanent change in teachers' attitudes and beliefs.

Attitudes play a significant role in determining the use of field activities in biology instruction. Teachers with positive attitudes are more likely to use out-of-class activities often than those with negative attitudes. Teacher training institutions should therefore ensure that fieldwork training in science is covered comprehensively so as to enable trainee teachers appreciate the role of out-of-class activities. The Kenya Institute of Curriculum Development should develop _framework' for science syllabus with process and content that can be offered through the use of out- of-classroom activities in locations and habitats close to the schools. Since teachers' skills play a significant role in the use of field activities, teacher training institutions need to train science teachers how to plan and organize out-of-class activities. This is a demanding task which can involve writing field assessments, ordering equipment, planning details and tasks for out-door activities. It will involve negotiating with colleagues, the head of departments, fieldwork providers and landowners, amongst others. All of this will need to be matched to suitable and desired learning outcomes. The teacher training institutions should ensure that science teachers are sufficiently confident and proficient to deliver outdoor activities with competence. This should include training in the use of formative assessment techniques/approaches. Online support for teachers and technicians should be developed. Good practice on out- door activities should be recognized and highlighted.

Findings from these research suggests that it is helpful to distinguish between: factors that can influence the provision of outdoor learning by schools, teachers and others factors that can influence the nature and quality of young people's learning in outdoor settings. It is clear that the provision of outdoor learning in schools is affected by a wide range of barriers and opportunities. Notable barriers include: (i) teachers ${ }^{6}$ knowledge on use of out-door activities; (ii) teachers' lack of skills and positive attitude toward teaching outdoors; (iii) secondary school curriculum requirements limiting opportunities for outdoor learning; (iv) shortages of time, resources and support; and (v) wider changes within and beyond the education sector. These various factors make clear the complexity of the challenge facing policy makers, practitioners and others who are seeking to increase and improve young people's access to learning beyond the classroom and the school. The research that has been undertaken into students' experiences of outdoor learning activities suggests that there are several factors that can facilitate and/or impede learning in outdoor settings. These can be conceptualized in terms of: program factors - including the structure, duration and pedagogy of outdoor education programs participant factors - including the characteristics, interests and preferences of learners; place factors - relating to the nature and novelty of the outdoor learning setting. Taken together, these factors provide a framework for thinking about how efforts to improve the quality and depth of young people's outdoor learning might be directed. Against the backdrop of calls for educational practice and policy to become more evidence-based, there is much in this research that is of relevance and use to teachers, policy makers and researchers. With this in mind, it is important that the findings of this research are considered not just in terms of how they might help to prove the value of outdoor learning, but also in terms of how can they might help to improve its quality. 


\section{Recommendations}

These recommendations have been developed to assist educational programs in determining and/or evaluating the typical responsibilities of teachers as they carry out out-door/ fieldwork instruction. These are statements describing the knowledge, skills, and attitudes that are needed to be successful in the role of field instruction. These recommendations are general statements that may be modified and should be considered a guideline for school settings.

\subsection{Knowledge}

Teachers should demonstrate understanding and comprehension of the information required for the multiple roles they assume. In addition to the recognized competencies for instruction, teachers must be able to facilitate the development of competent students through the provision of supervised quality fieldwork experiences; develop learning activities and assignments that encompass the breadth and depth of knowledge in out-of-class activities and reinforce knowledge and skills leading to quality learning. It is also recommended that teachers demonstrate knowledge of effective learning processes that identify individual learning styles and use appropriate and individualized techniques for students at their fieldwork education site; demonstrate accurate and current knowledge of the contractual agreement between the schools and the fieldwork site when necessary; demonstrate the competence to develop and maintain proficiency in the learning processes and supervision skills through investigation or self-study, and maintain current knowledge of standards, rules, and regulations regarding supervision of students set by the Ministry of Education, and the fieldwork provisions.

\subsection{Attitude}

Teachers should employ positive attitudes in the learning processes to make sound judgments and decisions within the context of their roles. It is recommended that teachers should effectively evaluate and share knowledge in the form of new materials, literature, and educational materials relating to fieldwork that enhance the lifelong learning in students; critically integrate and apply theory, literature, and research into practice at the fieldwork site; critically evaluate the curriculum, particularly in terms of its components and their relationship to out-door learning, and participate in curriculum development in relation to the best practice in the fieldwork setting. It is further recommended that teachers need to demonstrate the ability to encourage development of critical reasoning in students; project a positive image of the fieldwork program to the school, student, and community; demonstrate a competent and positive attitude towards practice and supervision that will result in effective development and mentoring of fieldwork activities and effectively supervise and advise students the role of out-of-classroom activities and expected learning outcomes. They should also identify and clearly communicate both strengths and areas for improvement to students in a manner that encourages student learning.

\subsection{Skills}

Science teachers should demonstrate the expertise, skills, proficiencies, and ability to competently fulfill

International Journal of Educational Studies Vol. 1, No. 4, pp. 240-250 2018

DOI: 10.53935/2641-533x.v1i4.93 Funding: This study received no specific financial support.

Acknowledgement: Author wish to express Acknowledgement: Author wish to express
sincere gratitude to the late Prof. Khaemba Ongeti for his tireless assistance and direction in Ongeti for his tireless assistance and direction in
the development and final completion of this the development and final completion of this
study. Special thanks go to the School of Education Moi University, lecturers and the Department of Curriculum, Instruction and Educational Media for allowing the use of the equipment and facilities and to the National Commission for Science, Technology and Innovation (NACOSTI) for approval to conduct this study.

Article History:

Received: 25 July 2018

Revised: 26 September 2018

Accepted: 1 November 2018

() 2018 by the authors; licensee Academic

ublishing Group their roles in guiding students during out-door activities. The teachers must also be able to plan fieldwork experiences within their settings that will prepare competent students; develop fieldwork course objectives, course materials, and educational activities and experiences that promote optimal learning for students; evaluate students' performance and learning outcomes in relation to fieldwork objectives and the biology curriculum and also design and implement a plan that develops and maintains accurate documentation of student performance in collaboration with school curriculum, and/or other documentation required for out-ofclassroom experiences.

\section{References}

Abelson, S. I. (1979). Educational psychology research. Journal of Social Research, 4(23), 142-147.

Ackermann, R. (1972). Windows into science classrooms problems associated with higher-level cognitive learning. London: Falmer Press.

Barker, S., Slingsby, D., \& Tilling, S. (2002). Teaching biology outside the classroom, is it heading for extinction? shrewsbury. Field Studies Councils.

Beasley, W., Butler, J., \& Satterthwait, D. (2001). Senior sciences future directions project final Report. Board of Senior Secondary School Studies (Unpublished): Queensland.

Brown, L. J., \& Cooney, T. P. (1982). Science centres and science learning. Studies in Science Education, 27(1), 53-98. 


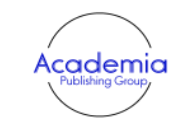

International Journal of Educational Studies Vol. 1, No. 4, pp. 240-250

2018

DOI: 10.53935/2641-533x.vli4. 93

Funding: This study received no specific

financial support.

Acknowledgement: Author wish to express sincere gratitude to the late Prof. Khaemba Ongeti for his tireless assistance and direction in the development and final completion of this study. Special thanks go to the School of Education Moi University, lecturers and the Department of Curriculum, Instruction and Educational Media for allowing the use of the equipment and facilities and to the National Commission for Science, Technology and Innovation (NACOSTI) for approval to conduct this study.

Article History:

Received: 25 July 2018

Revised: 26 September 2018

Revised. 26 September 2018

Accepted: I November 2018

the authors; licensee Academic

Publishing Group
Dillon, J., Morris, M., O`Donnell, L., Reid, A., Rickinson, M., \& Scott, W. (2005). Engaging and learning with the outdoors - the final report of the outdoor classroom in a rural context action research project. Slough, National Foundation for Educational Research.

Falk, J. F., Martin, W. W., \& Balling, J. D. (1999). The novel field-trip phenomenon, Adjustment to novel settings interferes with task learning. Journal of Research in Science Teaching, 15(2), 127-134.

Fastritzer, L. A., \& Boyer, M. M. (1983). Teacher beliefs and cultural models: A challenge for science teacher preparation programs. Science Education, 86(6), 821-839.

Fido, H. S., \& Gayford, C. (2002). Fieldwork and the biology teacher, a survey in secondary schools in England and Wales. Journal of Biological Education, 16(1), 27-32.

Frank, S., \& Enocks, M. (1982). Building social capital through outdooreducation. Journal of Adventure Education and Outdoor Learning, 8(2), 99-112.

Ginns, S., Waters, L., \& James, N. (1990). Mind the gap, why do people act environmentally and what are the barriers to proenvironmental behaviour? Environmental Education Research, 8(3), 239-260.

Haney, J. J., Lumpe, A. T., \& Czerniak, C. M. (2003). From beliefs to actions. The Beliefs and Actions of Teachers Implementing Change.

Haurey, H. J. (1994). A survey of current practice. Joumal of Biological Education, 37(1), 39-43.

Hillcox, S. (2003). The graduate ecologist's skills base. Unpublished Thesis; MSc ecology and management of the natural environment, University of Bristol. Journal of Science Teacher Education, 13(3), 171-187.

Hurd, J. (1982). Learning and knowledge. London: Paul Chapman Publishing.

Jones, A. (2000). Developing and sharing best practice in marine-related fieldwork. Occasional Publication No,8: University Marine Biological Station, Millport.

Kelsey, K., \& Steel, A. (2001). The truth about science: A curriculum for developing young scientists Arlington. VA: National Science Teachers Association.

Lucas, M., \& Pooley, R. (1982). Trends in science education, Learning, teaching and outcomes 1989-1997. Australian Council of Deans of Science: Melbourne.

Manning, G. (1982). Reading new environments: Students' ability to generalise their understanding between different ecosystems. International Journal of Science Education, 29(1), 67-100.

Michie, M. (1999). Science teachers talk about excursions. Science Teachers Association of the Northern Territory Journal, 17(1), 5679.

Ministry of Education. (2008). Secondary school biology manual, KLB.

Muse, C., Chiarelott, L., \& Davidman, L. (2002). Teachers' utilization of field trips, Prospects and problems. Clearing House, 56(3), $122-126$.

Mutebi, J., \& Matovu, W. H. (1993). Teaching with field trips. Journal of Geography in Higher Education, $18(1), 143-154$.

Nundy, S. (1999a). The fieldwork effect, the role and impact of fieldwork in the upper primary school. International Research in Geographical and Environmental Education, 8(2), 190-198.

Orion, N. (1993). A model for the development and implementation of field trips as an integral part of the science curriculum. School Science and Mathematics, 93(6), 325-331.

Pajares, J. (1992). Inquiring into inquiry learning and teaching in science. Washington, DC: American Association for the Advancement of Science.

Piaget, J. (1990). The mechanisms of perception. Routledge and Kegan Paul.

Price, S., \& Hein, G. E. (1999). More than a field trip, science programs for elementary school groups at museums. International Journal of Science Education, 13(5), 505-519.

Richardson, D. (1996). The philosophy of learning. Applied Environmental Education and Communication, 6(2), $49-66$.

Rokeach, M. (1972). The mirror system and its role in social cognition. Current Opinion in Neurobiology, 18(3), 179-184

Stepans, O., \& McCornack, G. K. (1985). Factors affecting teachers' participation in professional learning activities. Teaching and Teacher Education, 19(2), 149-170.

Tekaya, J. F., Martin, W. W., \& Barman, J. D. (2004). The novel field-trip phenomenon, adjustment to novel settings interferes with task learning. Journal of Research in Science Teaching, 15(3), 127-134.

Tukmen, J., \& Bonnstetters, L. (1999). Inquiry into life. New York: McGrawHill Higher Education.

Victor, H. (1991). What preservice teachers are surprised to learn about - and from - gifted students. Paper presented at the Paper Presented a the Annual Meeting of the American Educational Research Association: San Diego, CA.

Wenner, J. (1993). Creativity in science teaching NERC.

Woolfolk, H., \& Murphy, W. (1999). Developing science teachers‘ pedagogical content knowledge. Journal of Research in Science Teaching, 35(6), 673-695. 